\title{
The Net Greenhouse Gas Impact of the Sheppard Subway Line
}

\section{Submitted to Transportation Research Part D. Currently in review.}

Shoshanna Saxe (corresponding Author), University of Cambridge ss745@cam.ac.uk

Centre for Sustainable Development

Department of Engineering

University of Cambridge

Trumpington Street

Cambridge, CB2 1PZ, UK

Current address:

Department of Civil Engineering

University of Toronto

Sandford Fleming Building, Room 3001

10 King's College Road

Toronto, ON, M5S 1A4, Canada

Tel: 4168204082

Prof. Eric Miller, University of Toronto

miller@ecf.utoronto.ca

Department of Civil Engineering

University of Toronto

35 St. George Street, Room 305A

Toronto, ON, M5S 1A4, Canada

Tel: (416) 9784076 Fax: (416) 9786813

Prof. Peter Guthrie (OBE, FCGI FREng, FICE), University of Cambridge pmg31@cam.ac.uk

Centre for Sustainable Development

Department of Engineering

University of Cambridge

Trumpington Street

Cambridge, CB2 1PZ, UK 


\begin{abstract}
As cities work to reduce their total greenhouse gas (GHG) emissions, the transportation sector is lagging, accounting for a growing percentage of total emissions in many cities. The provision of public transit, and specifically urban rail transit, is widely seen as a useful tool for reducing urban transportation GHG emissions. There is, however, limited understanding of the net impact of new metro rail infrastructure on urban emissions. This paper examines the net GHG emissions the Sheppard Subway Line in Toronto, Canada. The GHG emissions associated with construction, operation, ridership and changes in residential density associated with the provision of the new metro rail infrastructure are assessed. These components are then combined and compared to calculate the net GHG impact across the study period, which extends from opening in 2002 through 2011. The GHG payback period is calculated. After nine years of operation, the Sheppard Subway Line is found to have nearly paid back its initial GHG investment in the optimistic case. The payback was due to the calculated mode shift from automobiles and changes in residential density and associated energy saving in the station pedestrian catchment areas. The payback period is very sensitive to the potential for induced demand to backfill the mode shifted automobile kilometres.
\end{abstract}

Keywords: Greenhouse gas emissions, metro rail, lifecycle impact

\title{
1. Introduction
}

The negative impact of greenhouse gas (GHG) emissions on climate change has been prominently discussed in the academic literature, in the press and by governments. International bodies, governments and citizens groups have called for a reduction in GHG emissions to avoid the most catastrophic impacts of climate change. To this end, many countries and cities have declared ambitious greenhouse gas reduction targets. In cities around the world, transportation emissions are an increasing percentage of all GHG emissions. While urban GHG emissions in other sectors have begun to decrease, the emissions due to transportation have largely held steady and make up an increasing fraction of total GHG emissions (Banister, 2011). The total transportation emissions and emissions per capita vary from city to city and are tied to urban form and the provision of public transport (Kennedy, Steinberger, Gasson, et al., 2009). The majority of urban transport emissions are due to road-based transport, particularly in cities and neighbourhoods that lack public transportation alternatives. This is due to the high number of trips that are made by automobile and the average GHG intensity of automobile travel, which is generally higher than other modes. The development of a robust public transportation system is often proposed to reduce urban transportation emissions. The provision of mass transit 
has been identified as a key opportunity in the reduction of global GHG emissions with the potential to save 25 GtC over 50 years (Pacala, 2004).

Globally, cities are expanding their urban rail networks (Newman, Kenworthy \& Glazebrook, 2013). There are many reasons to expand rail transport, such as congestion relief, expanding access to public transport, attracting development, and environmental stewardship. It is generally accepted that the development of urban rail reduces urban GHG emissions by reducing road-based transport emissions and encouraging density. In general, the literature supports this perception; studies have repeatedly shown that, per kilometre travelled, moving by public transport is 'cleaner' than driving a private vehicle (Newman, 2000). However, these studies often exclusively assess transport during operation, ignoring the GHG emissions associated with infrastructure construction, the uptake of new metro infrastructure by users of other modes, the potential for induced demand onto roads and the potential of transportation infrastructure to affect urban form.

This limitation in scope can mask the real GHG impact of new metro rail and hide the need for supporting policies and interventions to maximize the GHG benefit of rail infrastructure. As cities take action to reduce their GHG emissions, they need to understand the quantifiable effectiveness of proposed interventions of new metro rail infrastructure and under what conditions the GHG benefit will be maximized. For new transportation infrastructure projects, this evaluation should include an assessment of life cycle impacts of the infrastructure, actual mode shift and mode share patterns, and the ripple effects on urban form.

Life cycle thinking and consideration of GHG payback periods are emerging considerations in thinking about transportation infrastructure (Gallivan, Rose, Choe, et al., 2014). However, to date, few studies have looked at the GHG payback of metro rail infrastructure. Of the studies that have been published, the majority have focused on the lifecycle GHG impacts; less work has been done to assess the GHG savings associated with opening the line or the length of time and the behaviours/policies needed to payback the initial GHG investment. In particular, the impact on urban form is under-explored in the literature, though the GHG impacts of the connection between transport infrastructure developments and transport land use interaction is starting to be made (Nahlik \& Chester, 2014).

Chester and colleagues have found that the GHG emissions associated with rail systems increased by a factor of 1.6-2.5 when taking a lifecycle approach (Chester \& Horvath, 2009). In contrast to some other work in the area, Chester considered the lifetime of construction through individual structure types or materials rather than assigning a lifetime to the rail system as a whole: This ranges from substations with a lifetime of 20 years to concrete at 50 years (Chester, 2008). In other rail examples, construction emissions are predicted to account for $15 \%$ of the lifecycle emissions for Crossrail, a new rail line under construction in London (Paris \& de Silva, 2010) and the Hong Kong MTR attributes 11\% of total life cycle emissions for their railway to civil infrastructure embodied GHG (MTR, 2013). Crossrail and the MTR find much 
lower impacts from infrastructure in large part because they assess the projects over a much longer 120-year lifespan.

Calculating the GHG investment required to construct the rail infrastructure in theory facilitates assessment of the GHG payback period for the project. In practice, however, the GHG payback period of rail transport infrastructure has rarely been assessed. Of the available case studies, the first cases date from the 1970s oil crisis. In this period, Lave assessed the energy intensity of the BART System in San Francisco. The work does not address GHGs but is relevant as energy use and GHG emissions are highly correlated. Given the energy input in construction and the operational savings of ridership on the metro at the time, a payback period of 535 years was required (Lave, 1978). The long payback period was due primarily to the relative operational energy intensity of buses and metro at the time, buses required less energy per PKT and much of BARTs early ridership had shifted from the bus network. Rail vehicles are heavy, requiring more energy to move than a bus; for per capita energy impact to advantage rail more riders are needed per vehicle.

The contemporary challenge of GHG emissions and associated climate change has prompted a re-emergence of life cycle thinking in infrastructure. Assessments of the GHG benefit of rail infrastructure are starting to be compared to the life cycle GHG cost, in order to assess the net GHG impact. In general, the assessed benefits and the GHG payback period have been based on ridership impacts, namely the reduction in automobile use. In assessing the GHG payback period for the Gold Light Rail Line in Los, Angeles California, Chester et al (2012) found that a minimum mode shift from automobiles of $35 \%$ was required to payback the GHG investment of constructing the line (Chester, Eisenstein, Pincetl, et al., 2012). Travel surveys indicated that $67 \%$ of Gold Line users were previously driving leading to payback within the first decade of operation (Chester, Eisenstein, Pincetl, et al., 2012; Chester, Pincetl, Elizabeth, et al., 2013). Similarly, the predictions for Crossrail are that it will most likely payback the initial carbon investment in 9 to 13 years (Paris \& de Silva, 2010). This payback period is based on a calculation of 530 million fewer vehicle kilometres (VKT) travelled in London after opening of Crossrail (Paris \& de Silva, 2010). The calculated GHG paybacks in both of these examples are heavily dependent on reductions in private automobile use. The potential for releasing unmet travel demand onto the roads is not discussed. In addition, the urban form impacts of new metro rail were not included in either of these assessments. New automobile users induced onto the road would mitigate the GHG savings associated with mode shift. Changes in urban form, specifically densification around transit nodes, have the potential to lead to meaningful GHG savings. A full assessment of the GHG impact should consider these two factors.

Researchers are now exploring the opportunities for combining urban development policies and transit infrastructure to reduce GHG emissions (Nahlik \& Chester, 2014; Kimball, Chester, Gino, et al., 2013). The existing work mostly evaluates future potential GHG savings and is based on projections of what might happen, rather than measurements of observed changes around an existing rail system assesses in 
this paper. These predictions show that, through a coupling of transportation and land use planning, there is a large potential for GHG savings. Looking at the Phoenix LRT, Kimball et al (2013) found a potential GHG saving of $36 \%$ by combining densification planning with public transport deployment compared to business as usual (Kimball, Chester, Gino, et al., 2013). The yearly potential saving in GHG is calculated to be 1,700 to 230,000 $\mathrm{MgCO}_{2} \mathrm{e}$, ranging with the achieved residential density (Chester, Nahlik, Fraser, et al., 2013). Similar results were found in LA, where up to $40 \%$ of GHG emissions could be avoided through combined transit and land use planning (Nahlik \& Chester, 2014).

As cities increasingly turn to rail transit to meet their mobility requirements, a greater understanding of the net GHG impact of new rail infrastructure is needed. The existing literature has looked at the lifecycle GHG impact of rail infrastructure in only a few cities. The published work is focused on surface rail rather than underground systems and has only started to include urban form effects in calculating the life cycle benefit. This research expands understanding of the lifecycle GHG impact of rail infrastructure by assessing underground rail through based on measured rather than predicted outcomes. Detailed assessments of the GHG impact of the Sheppard Subway on ridership and land use can be found in Saxe, Cruickshank \& Miller, 2015 and Saxe, Cruickshank \& Miller, 2016. This paper investigates the combined GHG impact of construction, operation, ridership patterns and changes in urban form associated with the Sheppard Subway Line in Toronto. The GHG payback period is calculated and sensitivity tested.

\subsection{The Sheppard Subway Line}

The Toronto Sheppard Subway Line opened in 2002 bringing subway access to a new part of Toronto. It is $5.5 \mathrm{~km}$ long running between Sheppard-Yonge and Don Mills Stations. FIGURE 1 illustrates the Sheppard Line within metro public transit in Toronto. 


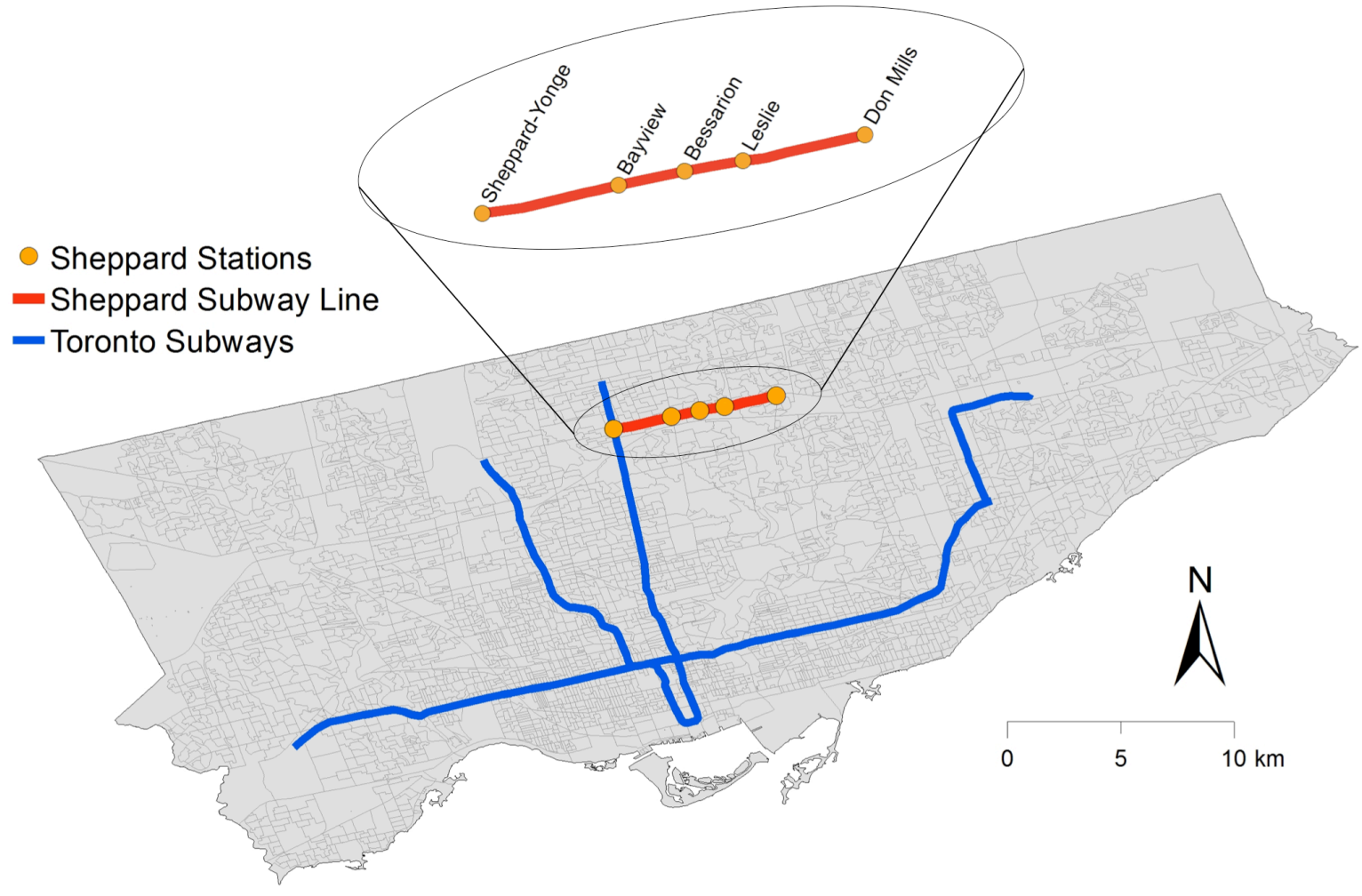

FIGURE 1 Toronto Transit Commission Subway Route Map (Saxe, Cruickshank \& Miller, 2015)

\section{Methods}

The GHG from construction is estimated from available construction data and correlations to the literature. The operational GHG is calculated from operational energy requirements provided by the operating transit authority and published GHG-energy intensity conversation factors. The impacts of changes in ridership behaviour are assessed through an analysis of ridership counts and on-board surveys. Longitudinal changes in mode share are assessed using transit survey data For further details on calculation of the operational GHG cost and savings through ridership behaviour refer to Saxe et al 2015b (Saxe, Cruickshank \& Miller, 2015). The relationship between new metro and changes in residential density is investigated by comparing the change in accessibility provided by the case study metro lines and the subsequent observed changes in residential density and by a quasi-experimental analysis of the changes in residential density compared to controls, refer to (Saxe, Cruickshank \& Miller, 2016). The GHG impact of changes in residential density is calculated from the relationship between residential density 
Saxe, Miller, Guthrie

and energy expenditure reported in the 2006 Canadian long form census (Statistics Canada, 2006c).

\subsection{Study boundaries}

Saxe et al (2015) propose a holistic assessment of the GHG impacts of new rail infrastructure (Saxe, Gerard, Guthrie, et al., 2015) shown in FIGURE 2. Another framework for assessing the GHG impacts is provided by the American Public Transportation Association (APTA) (APTA climate change standards working group, 2009). However, with its focus on calculating yearly emissions, the APTA recommendations do not consider construction emission as central to the GHG impact (as they are the emissions of others i.e. Steel manufacturers) or provide much discussion on the impact of induced demand. Similarly as this research deals with a specific infrastructure project, the land use multitier approach proposed by APTA - which is meant for regional scale assessments - is not appropriate at this scale.

While efforts were made to analyse all of the identified factors in the GHG impact of new rail infrastructure, due to data limitations some elements are excluded. FIGURE 2 highlights the elements included in this research. Elements highlighted in bold are analysed in detail using case study specific data; those in italic are touched on or assessed through the literature. Those left in standard type are outside the scope of this work. The construction of new transportation infrastructure will have many ripples on the development of a city, its urban form and travel mode share breakdown. This study focuses on the local effects within $3.2 \mathrm{~km}$ ( 2 miles) of the new subway and the marginal impact of adding the case studies to the existing local transit network.

Key exclusions include:

1) Other infrastructure not built: Enough provision of one type of transport infrastructure has the potential to reduce the need for other types of transportation infrastructure, eventually resulting in less construction and a reduction in GHG emissions

2) The assessment of GHG has been limited to the civil infrastructure. The impacts of constructing, maintaining and replacing the mechanical vehicles required are excluded. For urban rail, the GHG impact of the vehicles is between $2 \%$ and $4 \%$ of the total (Chester, 2008).

3) The impact of changes in urban form on commercial and industrial energy use is excluded from this research. Data on commercial and industrial energy use was not available in Toronto; further, data on the location of employment in the study area was not available at a sufficient resolution to separate the station catchment area from the surrounding land uses. In 
addition, there is a risk that intensified land use displaces more energy intensive jobs such as manufacturing. This requires more research.

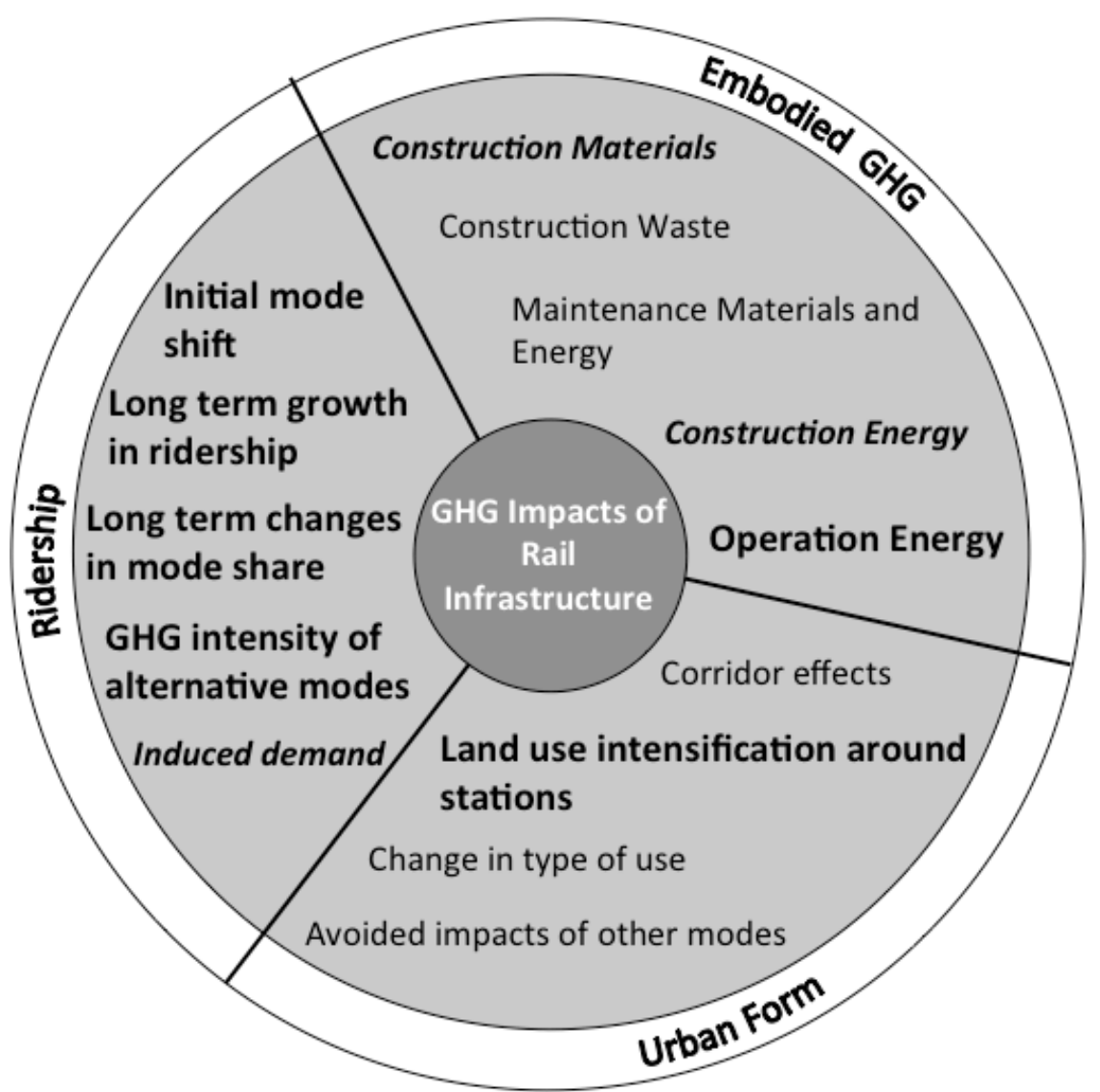

FIGURE 2 Elements of holistic assessment included in current research (After Saxe et al., 2015).

\section{Calculations}

\subsection{The greenhouse gas impact of construction}

The construction of new metro infrastructure necessitates the use of significant amounts of materials and energy. GHG emissions associated with construction activities are due to:

(1) Manufacturing of construction materials, including mineral extraction by mining, logging, and processing of raw materials;

(2) Direct construction energy consumed onsite; and 
Saxe, Miller, Guthrie

(3) Transportation energy used in movement of people, materials and machinery to and from site (Soga, Kidd, Hughes, et al., 2011).

The construction industry consumes a massive amount of new and recycled materials, from concrete and steel to wood and plastics. Before it can be used for construction, each material must be extracted, processed and transported to site. This process is very energy and resource intensive. Significant environmental impacts are embodied in the use of any material for construction. In Canada in 2012, the construction industry consumed 92 PJ of energy (Nyboer \& Bennett, 2015). The word wide impacts of construction materials on global GHG emissions are significant. For example, annually, 1.45 giga Tonnes of cement is produced worldwide accounting for $5 \%$ of global anthropogenic $\mathrm{C}_{2}$ emissions. In Toronto, the GHG intensity of 20 MPA concrete is $0.084 \mathrm{kgCO}_{2 \mathrm{e}} / \mathrm{kg}$ (assuming a concrete density of $2400 \mathrm{~kg} / \mathrm{m} 3$ ) (Athena Sustainable Materials Institute, 2005) and the GHG intensity of steel rebar is $0.602 \mathrm{kgCO}_{2 \mathrm{e}} / \mathrm{kg}$ (Athena Sustainable Materials Institute, 2002). For scale, the annual average Canadian GHG emission are 20.6 metric tonnes per person (Environmenat and Climate Change Canada, 2016).

Construction of the Sheppard subway line required $6.2 \mathrm{~km}$ of new twin tunnels, 4 new stations and the expansion of the existing Sheppard Station on the YongeUniversity-Spadina Line into the interchange station Sheppard-Yonge.

\subsubsection{Tunnels}

The Sheppard Subway Line was constructed using a combination of cut and cover excavation and bored tunnels. The running tunnels range from 15 to $18 \mathrm{~m}$ below ground and are $13 \mathrm{~m}$ apart. Reinforced segmental concrete lining was used to support the tunnels (Transit Toronto, 2012) which have an internal diameter of 5.2 m (Canadian Consulting Engineer, 2002). The Toronto Transit Commission provided key quantities of concrete and rebar used in the construction of the Sheppard Subway. For each metre of tunnel, $11 \mathrm{~m}^{3}$ of concrete and 8.8 tonnes of rebar was used (Toronto Transit Commission, 2013).

\subsubsection{Stations}

The stations were built using cut and cover bottom up construction. Soldier pile and lagging support was the most commonly used retaining wall system. Interlocking secant pile walls were also used at headwalls and at Sheppard-Yonge Station. Both anchors and props were used for lateral support (Anchor Shoring, 2013b, 2013a). TABLE 1 lists the concrete and rebar quantities used in construction of the Sheppard Subway Line stations. At Sheppard-Yonge Station, Bayview Station and 
Saxe, Miller, Guthrie

Don Mills Station the adjacent cut and cover excavated sections are included (e.g. wye structures and crossover tracks).

TABLE 1 Concrete and rebar use for Sheppard Stations (Toronto Transit Commission, 2013)

\begin{tabular}{|l|l|l|}
\hline Station Name & $\begin{array}{l}\text { Total } \\
\text { Concrete } \\
\left(\mathrm{m}^{3}\right)\end{array}$ & $\begin{array}{l}\text { Total } \\
\text { Rebar } \\
\text { (tonnes) }\end{array}$ \\
\hline $\begin{array}{l}\text { Sheppard-Yonge Station, } \\
\text { Cross-over \& Wye } \\
\text { Structures }\end{array}$ & 82,500 & 14,362 \\
\hline $\begin{array}{l}\text { Bayview Station \& Cross- } \\
\text { over Structures }\end{array}$ & 39,975 & 5,400 \\
\hline $\begin{array}{l}\text { Bessarion Station } \\
\text { Leslie Station }\end{array}$ & 20,856 & 3,420 \\
\hline $\begin{array}{l}\text { Don Mills Station, Cross- } \\
\text { Over, Tail Track Structures } \\
\text { \& Parking Deck }\end{array}$ & 37,130 & 3,548 \\
\hline
\end{tabular}

\subsubsection{Estimate of capital GHG}

Overall, the construction of the Sheppard Subway Line required 358,851 $\mathrm{m}^{3}$ of concrete and 40,000 tonnes of rebar (Toronto Transit Commission, 2013). These equate to GHG emissions of $96,482 \mathrm{tCO}_{2}$ e for the concrete and rebar use alone. The concrete and steel rebar assessed here is assumed to contribute the bulk of the construction material GHGs. Materials, however, are not the only contributors to construction GHG. In an assessment of Crossrail in London, the material use accounts for $57.6 \%$ of the total GHG emissions (Paris \& de Silva, 2010). Assuming this relationship holds for the Sheppard Subway, the total GHG emissions for the Sheppard Subway Line are 167,503 $\mathrm{tCO}_{2} \mathrm{e}$. The Sheppard Subway took eight years to construct equating to an annual average GHG impact of 20,938 $\mathrm{tCO}_{2} \mathrm{e} /$ year.

\subsection{Operation of the Sheppard Subway Line}

In 2012, operation of the Sheppard Subway Line consumed 22,940,200 kWh. The majority of the energy, $83 \%$, is used for traction energy with the remaining for station operation and routine maintenance. Since 2002, operation of the line has consumed a steady amount of energy plus or minus $10 \%$ (Wood, $\mathrm{P}$, personal communication). For the purposes of this research the yearly energy use is assumed constant (Saxe, Cruickshank \& Miller, 2015). 
The Sheppard Subway Line has run at a consistent service interval of 5 minutes 30 seconds since opening; this schedule is maintained Monday to Saturday from approximately 5:45 to 1:20 am, on Sundays trains start at 8 am. Over the course of a year, 73,855 trains run along the $11 \mathrm{~km}$ Sheppard Subway route (Toronto Transit Commission, 2011, 2014b). The effect of passenger weight on traction energy is ignored. The GHG intensity of travel on the Sheppard Subway is calculated from the PKT travelled per year, the traction energy used and publically available GHG intensity factors for electricity in Toronto (City of Toronto, 2014; Saxe, Cruickshank \& Miller, 2015). During the study period the operational GHG intensity of PKT on the line has reduced by $70 \%$, this is due mainly to changes in the local electricity mix and increases in ridership. FIGURE 3 illustrates the relative GHG intensity of the travel modes compared.

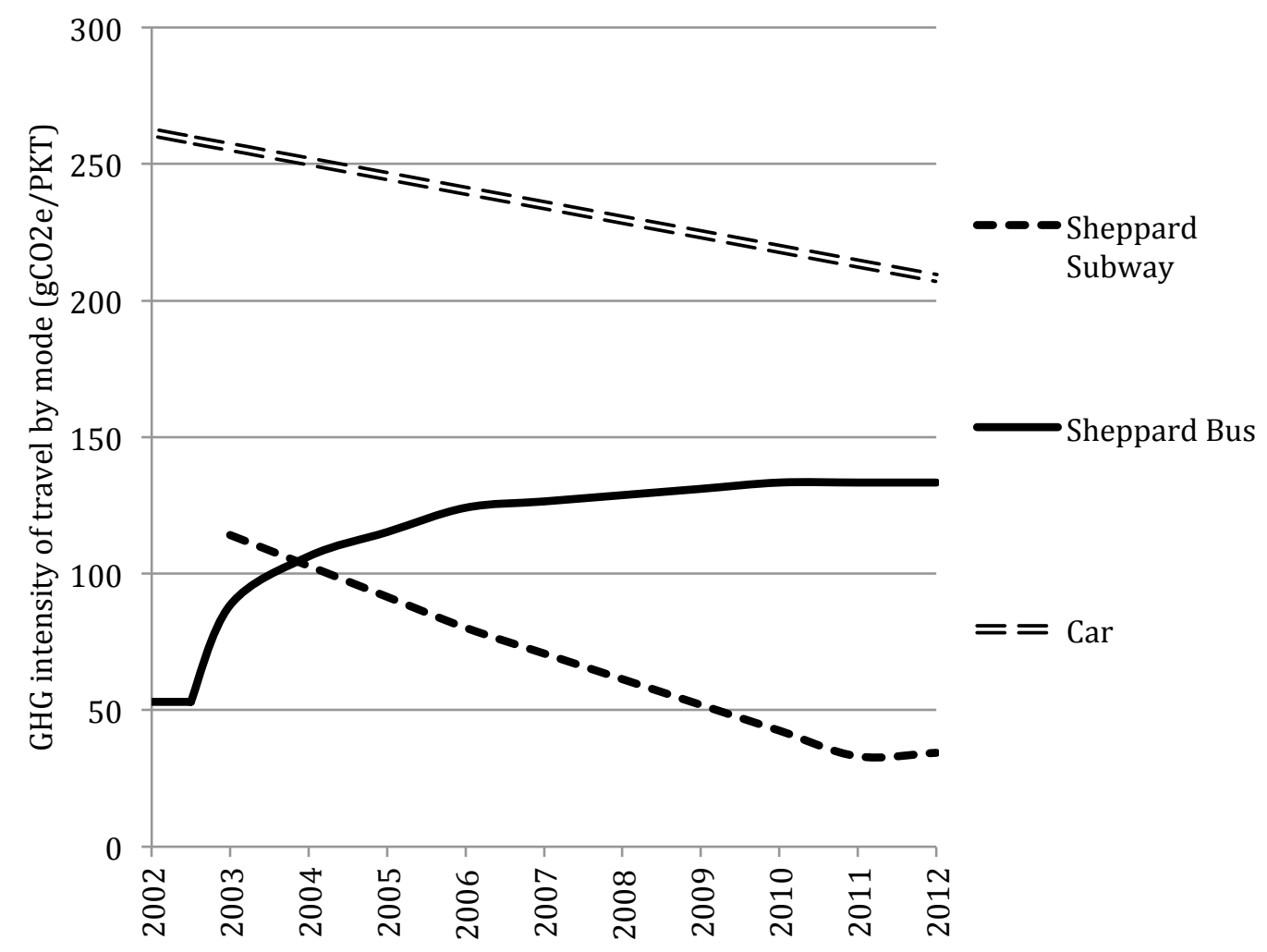

FIGURE 3 The GHG intensity of studied travel (VandeWeghe \& Kennedy, 2007; Toronto Transit Commission, 2014a, 2002, 2006, 2011, 2014c; City of Toronto, 2014)

\subsection{GHG savings from ridership}

Calculation of the GHG saving from changes in travel patterns associated with the Sheppard Subway Line is detailed in Saxe, Cruickshank \& Miller, 2015. In 2003, 152,884 PKT were travelled on the new Sheppard Subway. Forty-one percent of the initial ridership had previously been using buses along Sheppard Ave. The 
remaining ridership is assumed shifted from automobile users, though road counts do not observe a reduction in traffic on Sheppard. This could be due to many factors including long periods between road counts and high amount of through traffic. Through 2011, the number or PKT travelled on the subway increased by $44 \%$, some came from a further reduction in bus use but most would otherwise have been automobile drivers (Saxe, Cruickshank \& Miller, 2015). The relative GHG intensity of travel per mode is shown in FIGURE 3. Prior to opening of the Sheppard Subway, buses along Sheppard Ave were packed, much of this ridership then shifted to the subway. This resulted in a large increase in GHG per PKT for the remaining bus users. The GHG savings of PKT shifted from the bus to the Sheppard Subway are calculated based on the pre-subway bus use intensity.

The upper bound GHG savings from the Sheppard Subway Line ridership is calculated at $55.7 \mathrm{ktCO}_{2} \mathrm{e}$ between 2003 and 2011. FIGURE 4 illustrates the relative contribution of the reduction in bus and car use due to the initial mode shift and the long-term impacts of the growth in metro mode share, at the expense of the automobile, over time. This assessment includes the assumption that all PKT not shifted from Sheppard Ave buses would have been travelled by automobile. Little evidence was found of new trips induced because of the subway. Potentially critical to the overall GHG impact of the Sheppard Line, no reduction in traffic was observed. FIGURE 4 includes the increase in GHG emissions associated with the initial mode shift from bus, is this due to two factors, (1) until 2009 the GHG intensity of PKT on the subway was higher than on the pre-subway bus and (2) buses that ran parallel to the Sheppard Subway became emptier after opening producing more GHG/PKT than the pre-subway bus. 


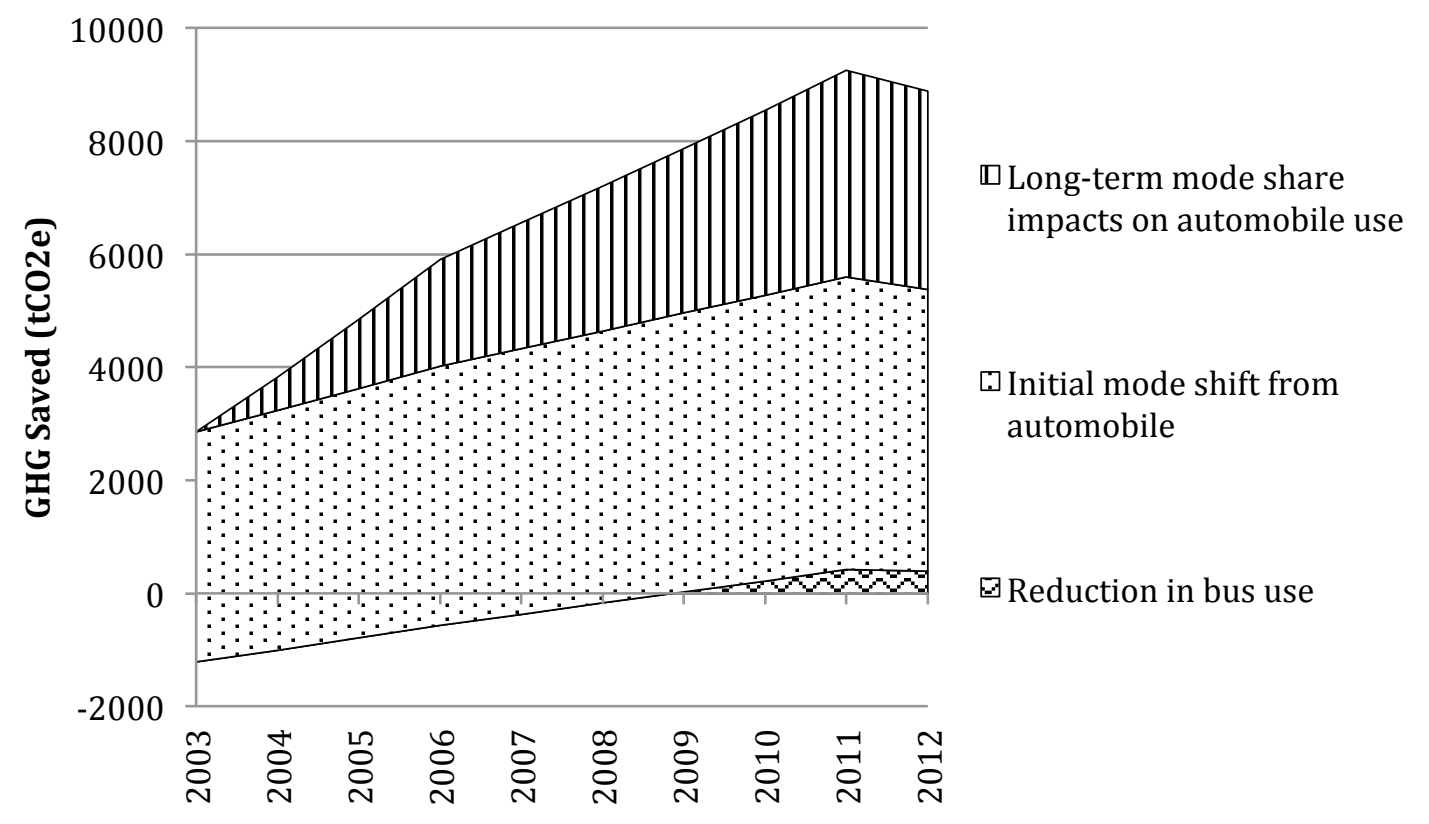

FIGURE 4 Net GHG saved through Sheppard ridership (Data ManagementGroup, 2001, 2006, 2011; Statistics Canada, 2001, 2006a, 2011a; Toronto Transit Commission, 2014a, 2014c; Traffic Data Centre and Safety Bureau, 2014c, 2014a, 2014b)

Induced demand may have significantly reduced the actual impact of any shifted travel. If $100 \%$ of the shifted automobiles were replaced by induced demand the net impact of the metro would have been a GHG increase of $29.4 \mathrm{ktCO}_{2} \mathrm{e}$. The literature indicates that an induced demand of $30 \%$ is common (Graham \& Glaister, 2004). Assuming a 30\% rebound in automobile traffic, the net GHG impact of ridership on the Sheppard Subway Line produces a savings of $30.2 \mathrm{ktCO}_{2}$ e from 2003 to 2011.

\subsection{GHG savings from residential density}

\subsubsection{Impact of the subway on residential density}

In addition to influencing travel mode choice and public transit ridership, the construction of new rail transit is often expected to influence land use by concentrating residences and employment around the stations (Cervero \& Landis, 1997; Kahn, 2007; Roukouni, Basbas \& Giannopoulou, 2012; Newman, 2006). This concentration has been shown to materialize in the presence of other critical mitigating factors, such as, demand for new homes and offices, supportive public 
policy and available land (Knight \& Trygg, 1977). The literature reports mixed outcomes; some projects have seen large changes in land use around new metro stations while others have not, often the land use impact varies from station to station within the same project (Knight \& Trygg, 1977; Cervero \& Landis, 1997).

Saxe and colleagues assess the relationship between the accessibility provided by the Sheppard Subway and changes in residential land use intensity from 2001 to 2011(Saxe, Cruickshank \& Miller, In Review). The results of a quantitative comparison of changes in accessibility to changes in residential land use as well as a quasi-experimental analysis comparing the station pedestrian catchment area (PCA) to controls found relationship between the opening of the Sheppard Line and increases in residential density. FIGURE 5 illustrates the results of the quasi-experimental analysis. Two types of controls were used: 1) the outer ring, a nearby control formed of a $1 / 2$ mile thick annulus around the PCA and 2) a matched pair controls based on 2001 residential density, job density and a measure of local deprivation. Deprivation is calculated using a method after Foth, Manaugh \& El-Geneidy, 2013 and is calculated from median household income, the unemployment rate, percentage of population that has immigrated to Canada in the 5 years before the census and the percentage of households that spend $30 \%$ or more or their income on rent. In 8 out of 10 comparisons that Sheppard Subway Station PCA saw faster residential growth than the controls.

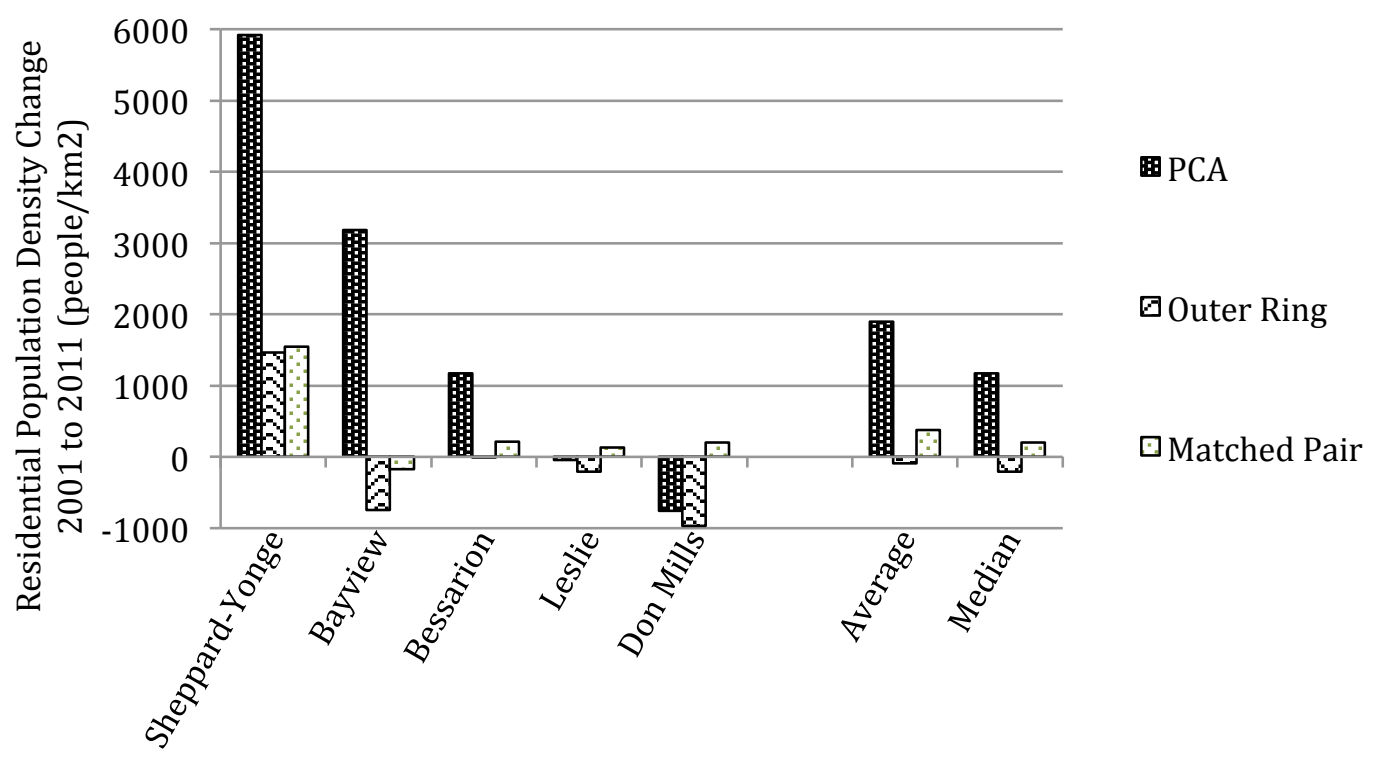

FIGURE 5 Changes in residential density 2001 to 2011 (Saxe, Cruickshank \& Miller, 2016)

The availability of land and zoning are known to have important impacts on the realization of land use intensity around new metro stations. This appears to have been the case along Sheppard where existing land uses varied from station to station and the zoning is prescriptive. 
The area was already widely developed, primarily with single-family homes before the construction of the Sheppard Subway Line. Around Sheppard-Yonge Station there were many high-rise towers but interspaced between them were large surface parking lots, prime land for redevelopment. Bayview Station's PCA consisted of single family homes, some schools with outdoor green space and Northeast of the station a commercial/industrial area with a large parking lot. Bessarion Station's PCA included a large commercial/industrial area to the Southeast and an area of residential apartment buildings to the west. A significant percentage of the Leslie Station PCA was parkland, through to the North there were high-rise residential buildings and to the South multi-storey hospital buildings. The Don Mills Station PCA was divided into four quadrants by two major roads, Sheppard Ave. and Don Mills Rd. The northeast quadrant was used for commercial purposes, the northwest and southeast were predominantly high-rise residential, and the southwest was low rise residential. Undeveloped green space surrounded the high-rise residential (Triathlon Inc., 1999). Sheppard-Yonge, where the greatest increase of land use intensity was observed, had available land in the form of parking lots. These lots, located next to existing tall buildings provided an ideal location for high-rise construction. Leslie Station, which nearly no change in residential density, had significant land limitations; much of the land in the Leslie catchment area consisted of parkland and hospital land, strong locked in uses. Don Mills Station had available land in the form of parks between existing high-rises but saw little development and lost population. The Tower in a Park paradigm is common across the city of Toronto which is now working to infill this type of land (City of Toronto, 2012).

Zoning was a barrier to development around the stations. Parts of each station's catchment are zoned mixed use, areas where strong new development could be expected. In addition, at Bayview and Don Mills stations, sections of the catchment areas are zoned for residential apartments. At Leslie station, however, a large swath is held for open space and a hospital. The dominant zoning across the station PCAs, and the study area as a whole, is low rise residential. This zoning is a significant barrier to intensified land use and limits the ability of the Sheppard Stations to influence residential and employment growth (C) OpenStreetMap contributors, 2015; Statistics Canada, 2011a; Toronto City Planning, 2013).

The impact on industrial and commercial land use has been excluded from this analysis. Sufficiently detailed spatial data showing the location of employment was unavailble for the study area. In addition, energy use for business, necessary to calculate their GHG impact in not available in Toronto. This would be an important area for future research should the data become available. 
Saxe, Miller, Guthrie

\subsubsection{Relationship between residential density and energy use/greenhouse gases}

Increasing land use intensity through higher concentration of residences is a path to reducing energy use and associated GHG emissions (Clark, 2013). Bigger houses tend to use more energy. This is due to many factors, including the increased conditioning loads associated with larger volumes and the greater exposed skin to volume ratio associated with freestanding homes (Ewing \& Rong, 2008; Ko, 2013; Steemers, 2003). With land use intensification, interior building volumes tend to decline and the incidence of shared walls increases while associated conditioning loads decrease (Clark, 2013). Smaller spaces can also require less lighting and have less room for appliances and electronics that use energy (Senbel, Church, Bett, et al., 2010). A neighbourhood's density is strongly related to housing type and size, important factors that affect energy use (Ko, 2013). Detached, single family homes are the most energy intensive housing type and are most likely to be found in low density neighbourhoods (Kellett, Christen, Coops, et al., 2013). Ewing and Rong (2008) found that compact development leads to approximately $20 \%$ reduction in residential energy use and GHG emissions compared to sprawl (Ewing \& Rong, 2008).

As part of the 2006 long form census, Statistics Canada collected data on the electricity and fuel expenditure for $20 \%$ of the population (Statistics Canada, 2012). Fuel refers to oil, gas, coal, wood or other fuels (Statistics Canada, 2006c) and is used primarily for space heating and cooking. Electricity is primarily used for appliances and lighting. Included in this analysis were people who reported their electricity and/or fuel payments separately from their rent or mortgage payments. Those who reported zero expenditure for electricity and fuel or whose energy costs are included in their rent or mortgage were excluded.

FIGURE 6 and FIGURE 7 illustrate the annual energy expenditure decrease in a household with increasing residential density.

The relationship between fuel expenditure and density is expressed by:

EQUATION 1: Toronto - Residential energy, electricity expenditure

$$
\text { Expense }_{\text {Electricity }}=1438-0.01243(\text { Density })
$$

EQUATION 2: Toronto - Residential energy, fuel expenditure

$$
\text { Expense }_{\text {Fuel }}=1921-0.02175(\text { Density })
$$

Where Expense Electricity $_{\text {and }}$ Expense $_{\text {Fuel }}$ are the annual average expenditure on electricity and fuel expressed in dollars and density is the residential population 
density expressed in people $/ \mathrm{km}^{2}$ calculated at Canadian 2011 Census Dissemination Area agglomeration. Density explained $8 \%$ of the variation in electricity cost and $18 \%$ of the variation in fuel cost. Both relationships have $\rho<0.0001$.

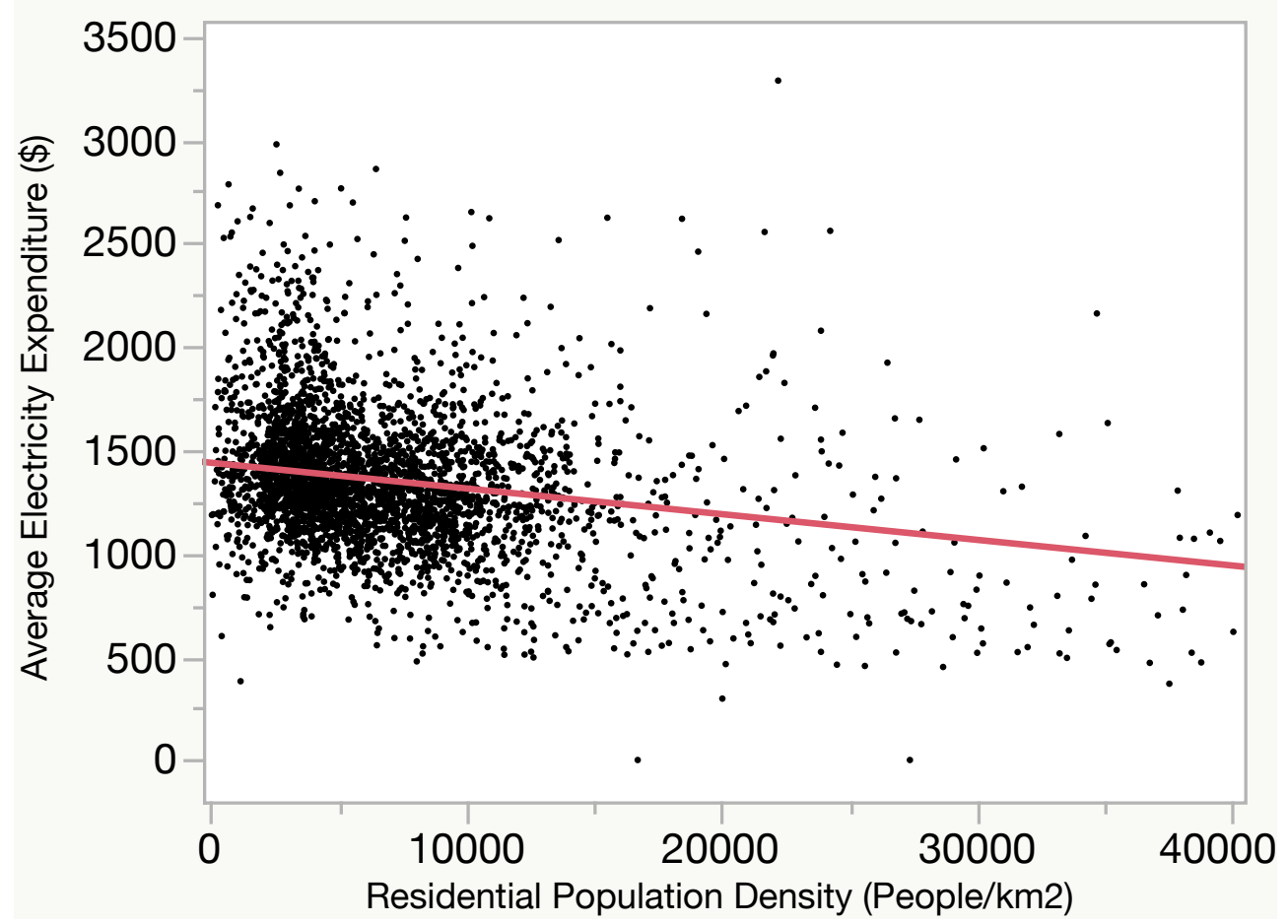

FIGURE 6 Residential density compared to annual residential electricity expenditure for the City of Toronto in 2006, $\mathbf{r}^{2}=\mathbf{0 . 0 8}$ (Author's own graphic based on data from Statistics Canada 2006a; Statistics Canada 2006b) 


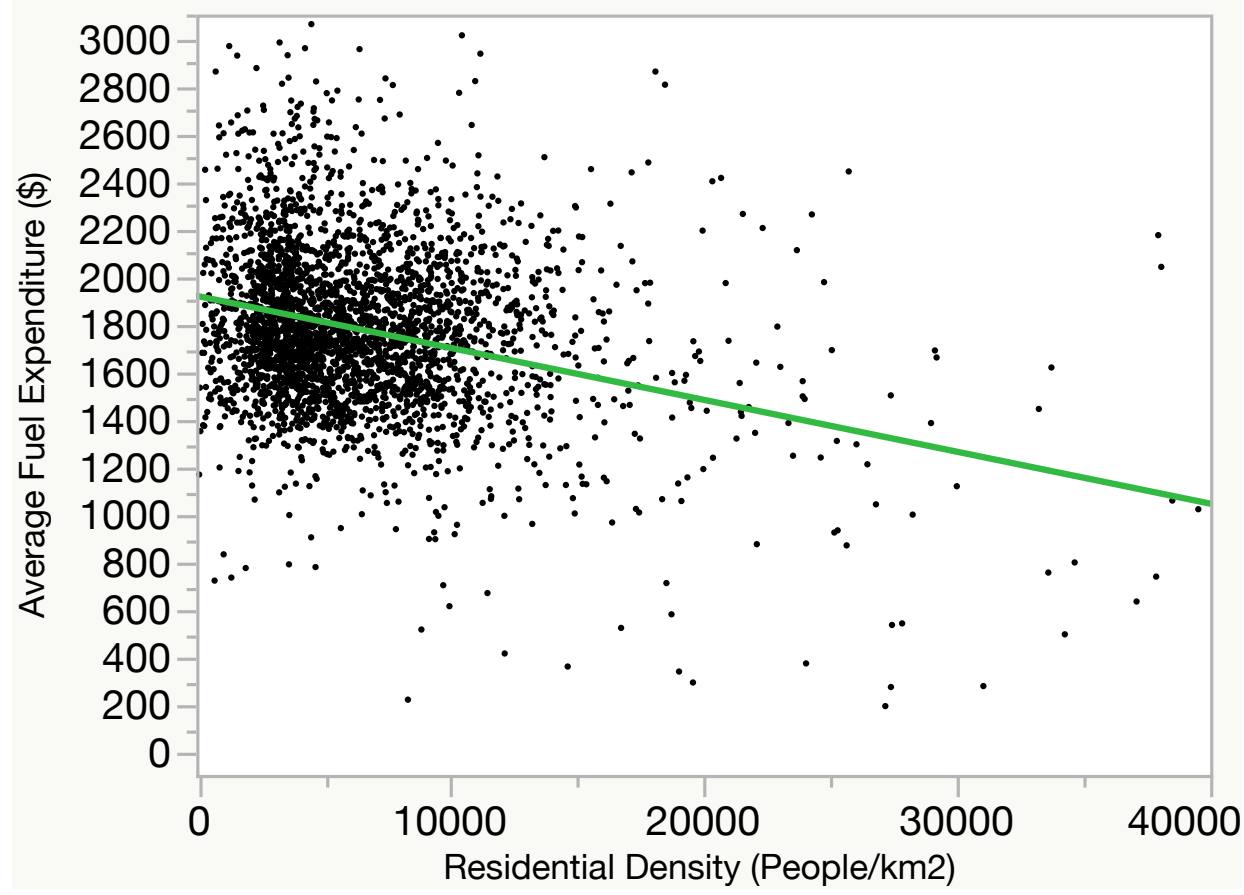

FIGURE 7 Residential density compare to annual fuel expenditure for the City of Toronto in 2006, $\mathbf{r 2}=\mathbf{0 . 1 8}$ (Author's own graphic based on data from Statistics Canada 2006a; Statistics Canada 2006b)

Energy expenditure is converted to GHG emissions using a method established by VandeWeghe and Kennedy 2007 (VandeWeghe \& Kennedy, 2007). TABLE 2 summarizes the conversion factors used to calculate the GHG emissions. Since bills are per household the average household size for each geographic unit was calculated and used to convert the expenditure to per capita. For illustration, the average household size for the City of Toronto in 2006 was 2.8 people (Statistics Canada, 2010).

TABLE 2 Summary of residential building energy conversion factors

\begin{tabular}{|c|c|c|c|}
\hline Energy Source & $\begin{array}{l}\text { Service and } \\
\text { regulatory charge }\end{array}$ & Cost per unit & GHG Intensity \\
\hline Electricity & $\$ 23.68 /$ month$_{(1)}$ & $6.122 \& / \mathrm{kWh}_{(1,2)}$ & $203.5 \mathrm{gCO}_{2} \mathrm{e} / \mathrm{kWh}(5)$ \\
\hline Natural Gas & - & $31.3223 \AA / \mathrm{m}^{3}(3)$ & $1890 \mathrm{gCO}_{2} \mathrm{e} / \mathrm{m}^{3}(6)$ \\
\hline Heating Oil & - & $82.62 థ / L_{(4)}$ & $2793.6 \mathrm{gCO}_{2} \mathrm{e} / \mathrm{L}(6)$ \\
\hline
\end{tabular}

(1) (Toronto Hydro, 2006) (2) (Ontario Energy Board, 2015a) (3) (Ontario Energy Board, 2015b) (4) (Statistica, 2015) (5) (City of Toronto, 2014) (6) (VandeWeghe \& Kennedy, 2007)

Converting the energy expenditure data to GHG emissions and comparing to density gives the relationship: 
Saxe, Miller, Guthrie

\section{EQUATION 3: Toronto - Residential density and GHG emissions}

$$
G H G_{\text {Residential }}=5.434-6.496 \times 10^{-5}(\text { Density })
$$

Where $\mathrm{GHG}_{\text {Residential }}$ is the combined emissions from electricity and fuel use expressed in $\mathrm{tCO}_{2} \mathrm{e} /$ capita and density is the residential population density expressed in people $/ \mathrm{km}^{2}$. Density explains $10 \%$ of the variance in calculated GHG emission and $\rho<0.0001$.

While the relationship is statistically significant, the rate of change in GHG emissions based on density is slow meaning large changes in density are needed to achieve significant GHG savings. To further investigate the relationship between the Sheppard Subway and energy use the quasi-experimental method is revisited.

A direct assessment of the station PCAs compared to their controls supports the finding of energy savings associated with the Sheppard Subway. The PCAs emitted lower GHG per capita than their controls in 7/10 comparisons. Bayview Station performed the poorest and had emissions 2\% larger than its outer ring and $27 \%$ larger than its matched pair. Don Mills Station had the best results outperforming its matched pair by $86 \%$. As shown in FIGURE 8, the PCAs had 10\% lower GHG emissions per capita (mean and median) than the outer ring and $1.5 \%$ (median) to $7.4 \%$ (mean) less GHG than the matched pair. The calculated savings in GHG ranged from $1.5 \%$ to $10 \%$. For the 47,482 residents on the PCAs in 2006 , this equates to a GHG saving from $3.2 \mathrm{ktCO}_{2} \mathrm{e} /$ year to $21.7 \mathrm{ktCO}_{2} \mathrm{e} /$ year. Given the moderate finding for the relationship between accessibility and density for the Sheppard Subway Line PCAs and the small but consistent impact on energy emissions, the average of the mean and median density savings is assumed in the optimistic case $(12.45$ $\mathrm{ktCO}_{2} \mathrm{e}$ /year). The impact of changes in urban form is assumed zero in 2003, the first year of operation, ramping up to the calculated $12.45 \mathrm{ktCO}_{2} \mathrm{e}$ in 2006 and held constant through 2011. This takes a conservative approach to any savings due to residential development in anticipation of the line and since 2006. For the less optimistic case the lower bound of the saving between the PCA and control is assumed at $3.2 \mathrm{ktCO}_{2} \mathrm{e} /$ year with the same ramp up pattern. 


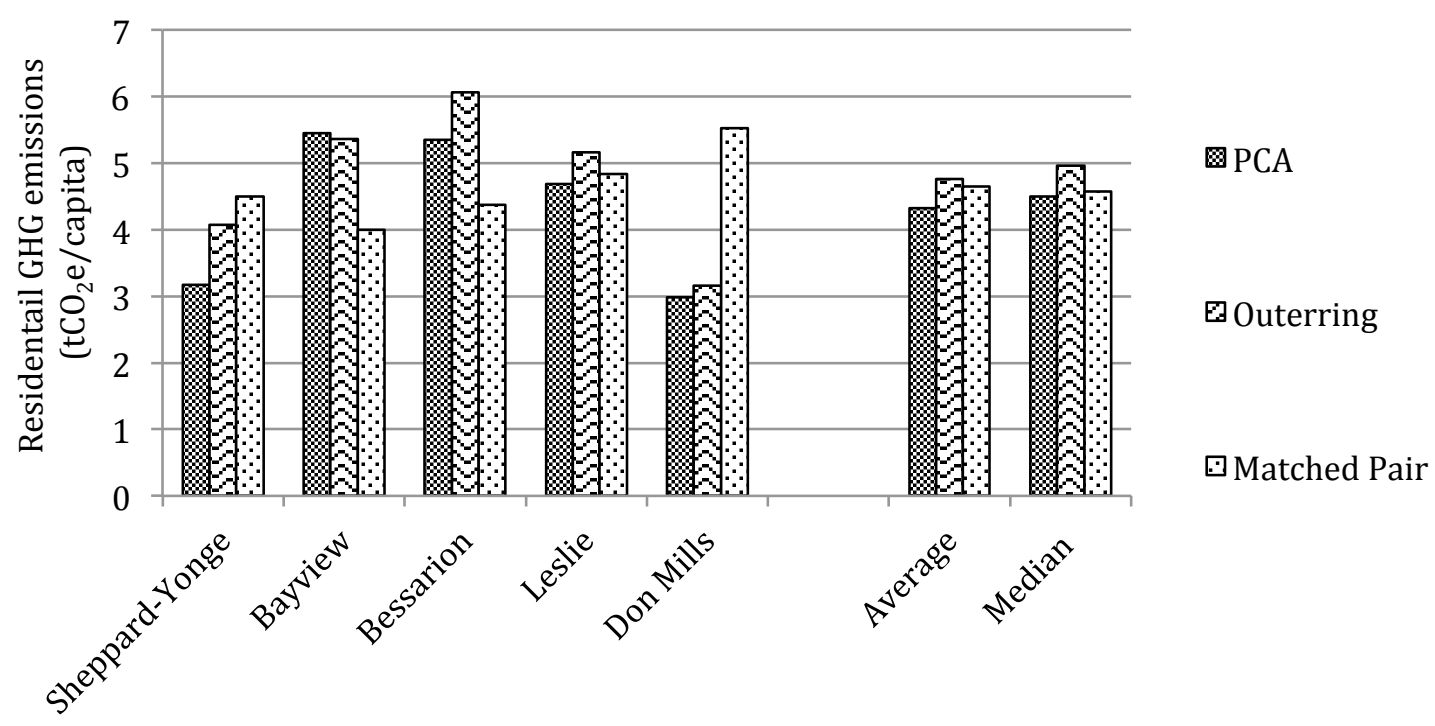

FIGURE 8 Annual residential GHG emissions, 2006 (Author's own graphic based on data from Statistics Canada 2006c; Statistics Canada 2006a; (C) OpenStreetMap contributors 2015)

\section{Results}

FIGURE 9 illustrates the annual and net GHG impact of the Sheppard Subway Line for the optimistic case. During the construction period the yearly impact has been taken as the annual average GHG emissions. In actuality, the emissions will vary year on year with changes in construction activity but such data was not available for this research. The GHG impacts of urban form are assumed to ramp up linearly over the first three years of operation and then hold steady, a conservative assumption. After a build up of GHG emissions during construction, the impacts of the new metro started to payback in its first year. In 2011, at the end of the study period the net GHG emission were $26.7 \mathrm{ktCO}_{2} \mathrm{e}$. Projecting into the future, applying the same trends observed through 2011, the Sheppard Subway Line was on track to payback its GHG investment in 2013, 11 years after opening. The reduction in automobile ridership associated with opening on the Sheppard Line and the associated changes in residential density were both critical to nearly achieving GHG payback during the study period. 


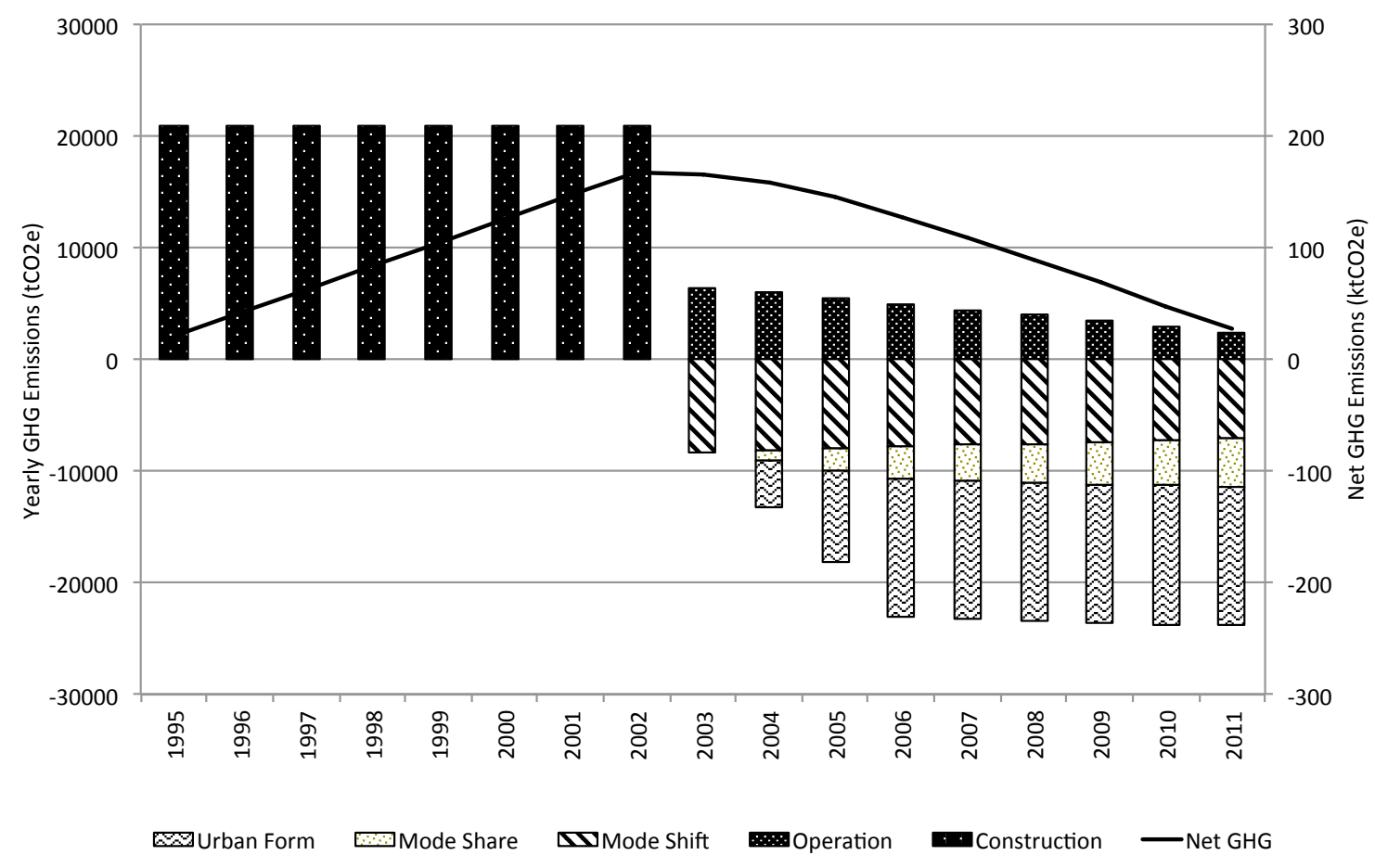

FIGURE 9 Annual and net GHG impact of the Sheppard Subway Line, optimistic case ( Author's own graphic based on data from Data ManagementGroup 2001; Data ManagementGroup 2006; Data ManagementGroup 2011; (C) OpenStreetMap contributors 2015; Statistics Canada 2011b; Toronto Transit Commission 2013b; Paris \& de Silva 2010)

In the optimistic case, above, no effect of induced demand on new automobile trips is assumed. Given experience from the literature and the observed traffic counts since opening of the Sheppard Subway. The urban form impact value used was based on the average of the calculated savings compared to the nearby and matched pair controls as discussed in section 3.4.

FIGURE 10 illustrates a less optimistic assessment of the GHG impact of the Sheppard Subway Line. In this less optimistic case, at the end of 2011 the net GHG impact is $105 \mathrm{ktCO}_{2} \mathrm{e}$, four times larger than in the optimistic case discussed above. To calculate this case, the lower bound of the GHG savings associated with changes in land use intensity around the stations is applied and induced demand of $30 \%$ is assumed to have offset some of the benefits of the mode shift and mode share changes from automobile travel. Based on this approach, and assuming the trends observed during the study period continue, the Sheppard Subway Line would be on track to payback the initial GHG investment by 2020.

Taking a more aggressive approach to the induced demand to reflect the steady road counts along Sheppard Ave, leads to the pessimistic case illustrated in FIGURE 
11. Here an $80 \%$ induced demand is assumed significantly reducing the GHG savings applied from ridership behaviour. In this scenario the Sheppard Subway Line only achieves GHG payback in 2035, 33 years after opening.

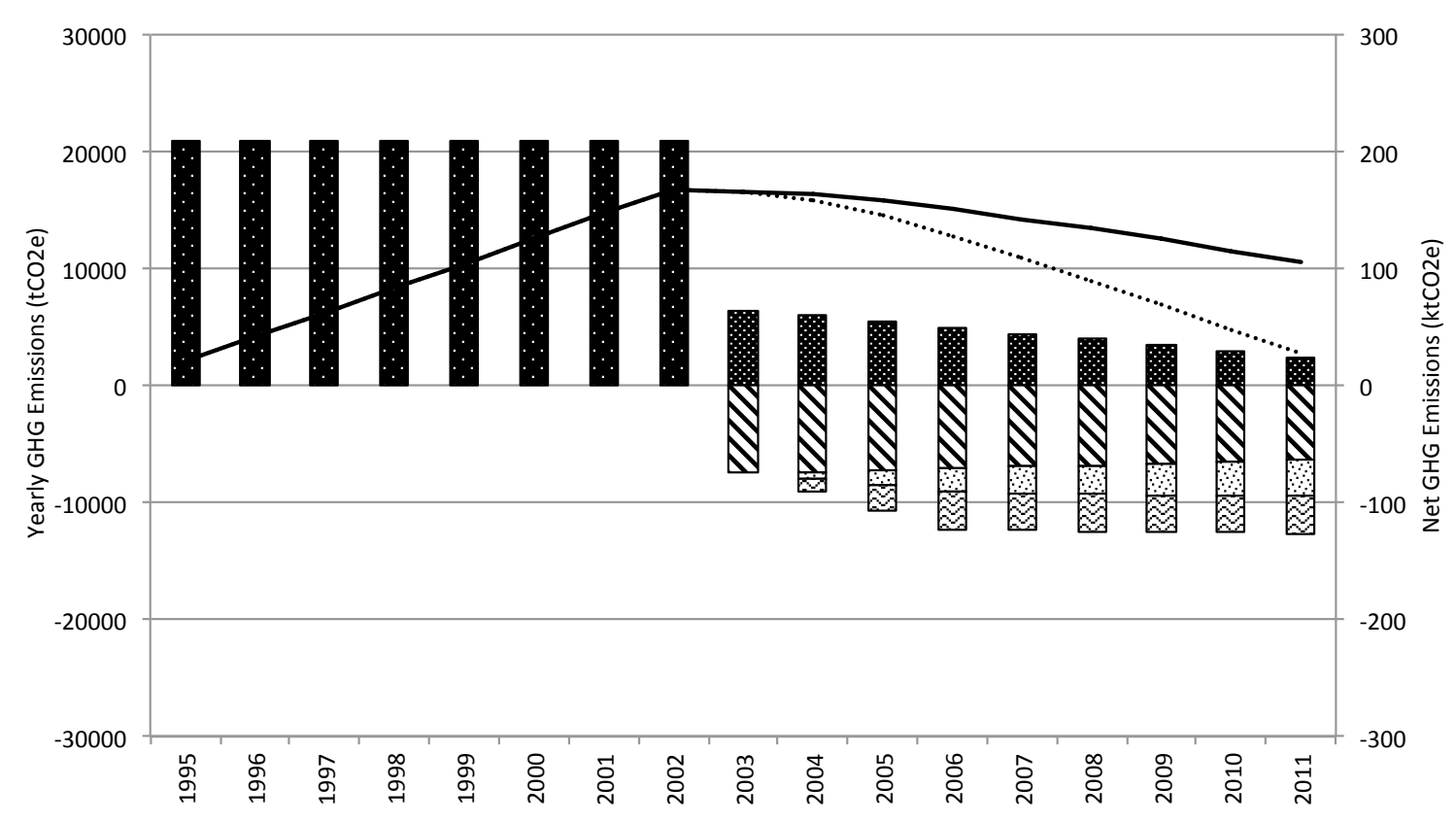

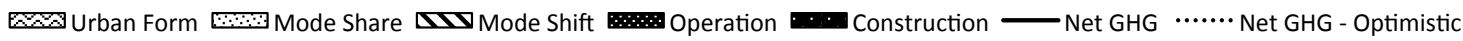

FIGURE 10 Annual and net GHG impact of the Sheppard Subway Line, less optimistic case ( Author's own graphic based on data from Data ManagementGroup 2001; Data ManagementGroup 2006; Data ManagementGroup 2011; C OpenStreetMap contributors 2015; Statistics Canada 2011b; Toronto Transit Commission 2013b; Paris \& de Silva 2010) 


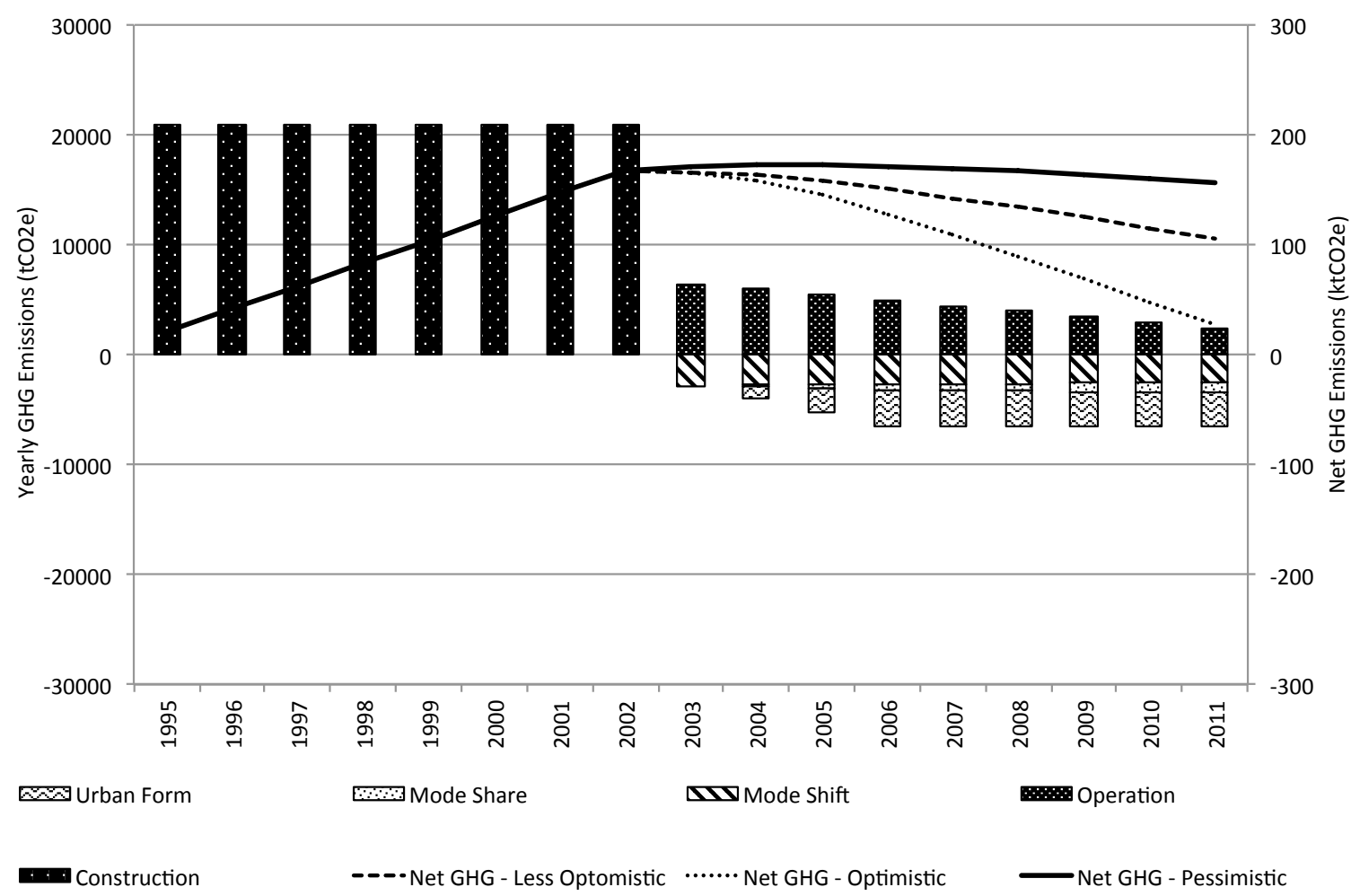

FIGURE 11 Annual and net GHG impact of the Sheppard Subway Line, pessimistic case ( Author's own graphic based on data from Data ManagementGroup 2001; Data ManagementGroup 2006; Data ManagementGroup 2011; (C) OpenStreetMap contributors 2015; Statistics Canada 2011b; Toronto Transit Commission 2013b; Paris \& de Silva 2010)

\section{Discussion}

The GHG payback of the Sheppard Subway line is dependent on PKT shifted from automobile travel and savings in energy use associated with increased density.

This calculation has assumed that all PKT not shifted from the Sheppard Ave Bus to the Subway come from automobiles, this assumption leads to a large number of automobile kilometres avoided. Large GHG savings materialize from these avoided PKT due to the relative GHG intensity of travel by automobile and by metro shown in FIGURE 3. Metro travel in Toronto benefits from the very low GHG intensity of electricity in the city, this proves to be critical for achieving GHG payback. This has been particularly important for PKT shifted from the buses. The low ridership on the Sheppard Subway in its early years - for a subway - compared to the high ridership of the Sheppard Bus - for a bus - combined with the GHG intensity of power each mode, meant that for 6 years each PKT shifted from buses led to a GHG increase rather than savings. As the Toronto electricity network became less GHG intensive the Sheppard Subway gained an advantage on the bus it replaced. With 
few savings realized from PKT shifted from buses the ridership impacts are very sensitive to induced demand. Assuming varying levels of induced demand changes the calculated GHG by decades. This is an area that needs further research in Toronto.

Quantitative and quasi-experimental analysis indicates that the Sheppard Subway did result in some concentration of development around its stations and an associated reduction in residential energy use. An assessment of the relationship between energy and density in Toronto found that while it was statistically significant the strength of the relationship and its slope were both small.

\section{Conclusion}

This paper finds that Sheppard Subway GHG payback has taken/will take between 11 and 35 years depending on optimistic to pessimistic approaches taken to automobile induced demand and changes in residential intensity. Payback would also be easier to achieve and faster if the GHG cost were lower. All three of these elements could be influenced through careful policy and design guidelines to 1) limit the use of unnecessary materials 2) limit automobile use rebound through induced demand and 3) encourage densification around metros.

A number of policies should be considered during the planning of new metro to facilitate rapid GHG payback and maximize long-term savings.

1) Reducing the capital GHG of new infrastructure: Concrete and steel, two major components of metro construction, are both GHG intensive materials. Leaner structures and/or smaller, simpler stations would reduce the capital GHG. At grade, track and stations require capital GHG investment an order of magnitude smaller than that required for tunnels and underground stations. Where possible, at grade track and stations should be considered. However, the land use impacts of surface tracks create an impassable barrier (not considered in this work) and could result in comparatively less service, which will impact the GHG benefit of the line. This should be considered against the savings of constructing at grade.

2) Push policies in coordination with expanded metro to reduce automobile use

GHG savings from mode shift will be limited, unless induced demand onto the roads is prevented. For shifts from other transit modes, the transit agency can control supply through altering, cancelling or changing the service schedule of bus routes and similar. The choice to use automobiles is more in the hands of the traveller. Push as well as pull incentives are needed to avoid nullification of GHG savings through mode shift and share impacts on automobile use. As the GHG intensity of all modes of travel continues to 
Saxe, Miller, Guthrie

reduce, the magnitude of the gap between PKT travelled by metro and by automobile will likely get smaller and require larger mode shifts to achieve the same GHG savings through metro projects. Push policies can include efforts to make driving more expensive (fees) and/or to make it slower (reductions in speed limit or traffic lanes).

3) Encourage densification around new metro stations

There is a large potential for GHG savings associated with increased land use intensity and associated reduction in residential energy use. Specific policies to support densification around the new stations missing at most stations in both cases. Incentives for densification can include appropriate zoning to facilitate development and/or tax incentives. Toronto has fairly strict zoning around the Sheppard Subway Stations but much of the station PCAs are excluded from the high land use intensity zoning.

\section{Acknowledgments}

This research was supported by the Commonwealth Scholarship Commission in the UK, The Natural Sciences and Engineering Research Council of Canada and The Canadian Centennial Scholarship Fund. 
Saxe, Miller, Guthrie

\section{References}

(C) OpenStreetMap contributors (2015) Open Street Map. [Online]. 2015. Open Database License. Available from: http://www.openstreetmap.org.

Anchor Shoring (2013a) Toronto Transit Commission Leslie Station. [Online]. 2013. The Anchor Group of Copanies. Available from: http://www.anchorshoring.com/content/view/57/66/ [Accessed: 26 June 2013].

Anchor Shoring (2013b) Toronto Transit Commission Yonge Station. [Online]. 2013. The Anchor Group of Companies. Available from: http://www.anchorshoring.com/content/view/56/65/ [Accessed: 26 June 2013].

APTA climate change standards working group (2009) Recommended practice for quantifying greenhouse gas emissions from transit. Group.

Athena Sustainable Materials Institute (2005) Cement and Structural Concrete Products: Life Cycle Inventory Update \#2. [Online]. Available from: http://www.athenasmi.org/tools/impactEstimator/companionReports/Cemen t_And_Structural_Concrete.pdf.

Athena Sustainable Materials Institute (2002) Cradle-to-gate life cycle inventory: Canadian and US steel production by mill type. [Online]. Available from: http://www.athenasmi.ca/tools/impactEstimator/companionReports/Steel_Pr oduction.pdf.

Banister, D. (2011) Cities, mobility and climate change. Journal of Transport Geography. [Online] 19 (6), 1538-1546. Available from: doi:10.1016/j.jtrangeo.2011.03.009 [Accessed: 31 October 2012].

Canadian Consulting Engineer (2002) Award of Excellence: Sheppard Subway Tunnels - Canadian Consulting Engineer - Canadian Consulting Engineer. [Online]. 2002. http://www.canadianconsultingengineer.com. Available from: http://www.canadianconsultingengineer.com/features/award-of-excellencesheppard-subway-tunnels/ [Accessed: 23 July 2015].

Cervero, R. \& Landis, J. (1997) Twenty years of the Bay Area Rapid Transit system: Land use and development impacts. Transportation Research Part A: Policy and Practice. [Online] 31 (4), 309-333. Available from: doi:10.1016/S09658564(96)00027-4.

Chester, M. V. (2008) Institute of Transportation Studies Life-cycle Environmental Inventory of Passenger Transportation in the United States Life-cycle Environmental Inventory of Passenger Transportation in the United. University of California, Berkeley.

Chester, M. V., Eisenstein, W., Pincetl, S., Elizabeth, Z., et al. (2012) Environmental Life-cycle Assessment of Los Angeles Metro's Orange Bus Rapid Transit and Gold Light Rail Transit Lines. [Online]. (September). Available from: http://hdl.handle.net/2286/R.A.94226. 
Chester, M. V. \& Horvath, A. (2009) Environmental assessment of passenger transportation should include infrastructure and supply chains. Environmental Research Letters. [Online] 4 (2), 1-8. Available from: doi:10.1088/17489326/4/2/024008 [Accessed: 5 October 2012].

Chester, M. V., Nahlik, M.J., Fraser, A.M., Kimball, M.A., et al. (2013) Integrating Lifecycle Environmental and Economic Assessment with Transportation and Land Use Planning. Environmental Science \& Technology. [Online] 47 (21), 1202012028. Available from: doi:10.1021/es402985g.

Chester, M. V., Pincetl, S., Elizabeth, Z., Eisenstein, W., et al. (2013) Infrastructure and automobile shifts: positioning transit to reduce life-cycle environmental impacts for urban sustainability goals. Environmental Research Letters. [Online] 8 (1), 015041. Available from: doi:10.1088/1748-9326/8/1/015041 [Accessed: 7 January 2015].

City of Toronto (2012) Infill on Apartment Sites in Toronto: A Ten Year Review. City of Toronto (2014) STAFF REPORT Toronto's 2012 Greenhouse Gas and Air Quality Pollutant Emissions Inventory.

Clark, T.A. (2013) Metropolitan density, energy efficiency and carbon emissions: Multi-attribute tradeoffs and their policy implications. Energy Policy. [Online] 53413-428. Available from: doi:10.1016/j.enpol.2012.11.006 [Accessed: 6 December 2012].

Data ManagementGroup (2001) The 2001 Transportation Tomorrow Survey. [Online]. Available from: http://www.dmg.utoronto.ca/transportationtomorrowsurvey/.

Data ManagementGroup (2006) The 2006 Transportation Tomorrow Survey.

Data ManagementGroup (2011) The 2011 Transportation Tomorrow Survey. [Online]. Available from: http://www.dmg.utoronto.ca/transportationtomorrowsurvey/.

Environmenat and Climate Change Canada (2016) Canadian Greenhouse Gas per Capita. [Online]. 2016. https://www.ec.gc.ca. Available from: https://www.ec.gc.ca/indicateursindicators/default.asp?lang=en\&n=79BA5699-1 [Accessed: 22 August 2016].

Ewing, R. \& Rong, F. (2008) The impact of urban form on U.S. residential energy use. Housing Policy Debate. [Online] 19 (1), 1-30. Available from: doi:10.1080/10511482.2008.9521624 [Accessed: 3 February 2014].

Foth, N., Manaugh, K. \& El-Geneidy, A.M. (2013) Towards equitable transit: examining transit accessibility and social need in Toronto, Canada, 1996-2006. Journal of Transport Geography. [Online] 291-10. Available from: doi:10.1016/j.jtrangeo.2012.12.008.

Gallivan, F., Rose, E., Choe, J., Williamson, S., et al. (2014) FHWA Infrastructure Carbon Estimator. [Online]. (September). Available from: https://www.fhwa.dot.gov/environment/climate_change/mitigation/publicati ons_and_tools/carbon_estimator/users_guide/page00.cfm.

Graham, D.J. \& Glaister, S. (2004) Road Traffic Demand Elasticity Estimates: A Review. Transport Reviews. [Online] 24 (3), 261-274. Available from: doi:10.1080/0144164032000101193.

Kahn, M.E. (2007) Gentrification Trends in New Transit-Oriented Communities: 
Saxe, Miller, Guthrie

Evidence from 14 Cities That Expanded and Built Rail Transit Systems. Real Estate Economics. [Online] 35 (2), 155-182. Available from: doi:10.1111/j.1540-6229.2007.00186.x.

Kellett, R., Christen, A., Coops, N.C., van der Laan, M., et al. (2013) A systems approach to carbon cycling and emissions modeling at an urban neighborhood scale. Landscape and Urban Planning. [Online] 11048-58. Available from: doi:10.1016/j.landurbplan.2012.10.002 [Accessed: 28 May 2013].

Kennedy, C., Steinberger, J., Gasson, B., Hansen, Y., et al. (2009) Greenhouse gas emissions from global cities. Environmental science \& technology. [Online] 43 (19), 7297-7302. Available from: http://www.ncbi.nlm.nih.gov/pubmed/19848137.

Kimball, M., Chester, M. V., Gino, C. \& Reyna, J. (2013) Assessing the Potential for Reducing Life-Cycle Environmental Impacts through Transit-Oriented Development Infill along Existing Light Rail in Phoenix. Journal of Planning Education and Research. [Online] 33 (4), 395-410. Available from: doi:10.1177/0739456X13507485.

Knight, R. \& Trygg, L. (1977) Evidence of land use impacts of rapid transit systems. Transportation. [Online] 6 (3), 1-23. Available from: doi:10.1007/BF00177453.

Ko, Y. (2013) Urban Form and Residential Energy Use: A Review of Design Principles and Research Findings. Journal of Planning Literature. [Online] 28 (4), 327-351. Available from: doi:10.1177/0885412213491499 [Accessed: 31 January 2014].

Lave, C.A. (1978) Transportation and Energy: Some Current Myths. Policy Analysis. 4 (3), 297-315.

MTR (2013) Sustainability Report 2013.

Nahlik, M.J. \& Chester, M. V. (2014) Transit-oriented smart growth can reduce lifecycle environmental impacts and household costs in Los Angeles. Transport Policy. [Online] 3521-30. Available from: doi:10.1016/j.tranpol.2014.05.004 [Accessed: 5 September 2014].

Newman, P. (2000) Sustainable Transportation and Global Cities. [Online]. 2000. Murdoch University, Insitiute for Social Sustainability. Available from: http://www.istp.murdoch.edu.au/ISTP/casestudies/Case_Studies_Asia/sustra ns/sustrans.html [Accessed: 14 October 2012].

Newman, P. (2006) Urban Design to Reduce Automobile Dependence. Opolis: An International Journal of Suburban and Metropoli- tan Studies. [Online] 2 (1), 3552. Available from: doi:10.1.1.370.8368.

Newman, P., Kenworthy, J. \& Glazebrook, G. (2013) Peak Car Use and the Rise of Global Rail: Why This Is Happening and What It Means for Large and Small Cities. Journal of Transportation Technologies. [Online] 03 (04), 272-287. Available from: doi:10.4236/jtts.2013.34029.

Nyboer, J. \& Bennett, M. (2015) Energy Use and Related Data : Canadian Construction Industry 1990 to 2010.

Ontario Energy Board (2015a) Historical Electricity Prices. [Online]. 2015. www.ontarioenergyboard.ca. Available from: http://www.ontarioenergyboard.ca/OEB/Consumers/Electricity/Electricity+P rices/Historical+Electricity+Prices [Accessed: 7 July 2015]. 
Saxe, Miller, Guthrie

Ontario Energy Board (2015b) Natural Gas Rates - Historical / OEB. [Online]. 2015. http://www.ontarioenergyboard.ca/. Available from: http://www.ontarioenergyboard.ca/oeb/Consumers/Natural+Gas/Natural+Ga s+Rates/Natural+Gas+Rates+-+Historical [Accessed: 7 July 2015].

Pacala, S. (2004) Stabilization Wedges: Solving the Climate Problem for the Next 50 Years with Current Technologies. Science. [Online] 305 (5686), 968-972. Available from: doi:10.1126/science.1100103.

Paris, R. \& de Silva, M. (2010) Crossrail Carbon footprint study - methodology and results.

Roukouni, A., Basbas, S. \& Giannopoulou, M. (2012) Land Use around Metro Stations : A Case Study. World Academy of Science, Engineering and Technology. 651-5.

Saxe, S., Cruickshank, H. \& Miller, E. (2015) Greenhouse Gas Impact of Ridership on Sheppard Subway Line, Toronto, Canada. Transportation Research Record: Journal of the Transportation Research Board. [Online] 250262-70. Available from: doi:10.3141/2502-08.

Saxe, S., Cruickshank, H. \& Miller, E.J. (2016) The Sheppard Subway Line Toronto: Changes in residential land use intensity 2001 to 2011. In: Transportation Research Board 95th Annual Meeting. 2016

Saxe, S., Gerard, C., Guthrie, P., Soga, K., et al. (2015) Greenhouse Gas Consideration in Rail Infrastructure in the UK. Proceedings of the ICE - Engineering Sustainability. [Online] Available from: doi:10.1680/ensu.15.00015.

Senbel, M., Church, S., Bett, E., Maghsoudi, R., et al. (2010) Urban Form \& GHG Emissions: A Primer for Municipal Decision Makers.

Soga, K., Kidd, A., Hughes, L., Guthrie, P., et al. (2011) Carbon dioxide from earthworks: a bottom-up approach. Proceedings of the ICE - Civil Engineering. [Online] 164 (2), 66-72. Available from: doi:10.1680/cien.2011.164.2.66 [Accessed: 27 June 2013].

Statistica (2015) Canadian home heating oil - average price in Toronto 2011. [Online]. 2015. http://www.statista.com. Available from: http://www.statista.com/statistics/198674/average-price-of-home-heatingoil-in-toronto-since-1990/ [Accessed: 7 July 2015].

Statistics Canada (2001) 2001 Cumulative Profile, Toronto, [data file]. Statistics Canada (2006a) 2006 Cumulative Profile, Toronto, [data file]. Statistics Canada (2011a) 2011 Cumulative Profile, Toronto [data file].

Statistics Canada (2010) Census trend for Toronto, 2006, 2001 and 1996 censuses. [Online]. 2010. www12.statcan.gc.ca. Available from: https://www12.statcan.gc.ca/census-recensement/2006/dp-pd/92-596/P12.cfm?Lang=eng\&T $=\mathrm{CMA} \& \mathrm{PRCODE}=35 \& \mathrm{GEOCODE}=535 \& \mathrm{GEOLVL}=\mathrm{CMA} \& \mathrm{TID}=$ 0 [Accessed: 7 July 2015].

Statistics Canada (2012) Dissemination area (DA) - Census Dictionary. [Online]. 2012. https://www12.statcan.gc.ca. Available from: https://www12.statcan.gc.ca/census-recensement/2011/ref/dict/geo021eng.cfm [Accessed: 17 June 2015].

Statistics Canada (2011b) Population, urban and rural, by province and territory (Canada). [Online]. 4 February 2011. Statistics Canada Website. Available from: 
Saxe, Miller, Guthrie

http://www.statcan.gc.ca/tables-tableaux/sum-som/101/cst01/demo62aeng.htm [Accessed: 20 January 2014].

Statistics Canada (2006b) Private Households in Non-band Non-farm Non-reserve Occupied Private Dwellings by Annual Shelter Costs Statistics (91) for the Dissemination Areas in the City of Toronto, 2006 Census - 20\% Sample-based Data.p.1.

Statistics Canada (2006c) Private Househols in Non-band Non-reserve Occipied Private Dwellings by Annual Shelter Costs Statistcs (91) for the Dissemination Areas in the City of Toronto, 2006 Census -20\% Sample-based data.p.1.

Steemers, K. (2003) Energy and the city: density, buildings and transport. Energy and Buildings. [Online] 35 (1), 3-14. Available from: doi:10.1016/S03787788(02)00075-0.

Toronto City Planning (2013) Citywide Zoning By-law.p.1.

Toronto Hydro (2006) Residential Rates 2006.p.4.

Toronto Transit Commission (2014a) Bus Riding Counts - On/Off Summary Reports.

Toronto Transit Commission (2014b) Service summary. [Online]. 2014. TTC.ca. Available from:

http://www.ttc.ca/Routes/General_Information/Service_Details.jsp [Accessed: 24 July 2014].

Toronto Transit Commission (2002) Service Summary November 24, 2002 to January 4, 2003.

Toronto Transit Commission (2006) Service Summary November 26, 2006 to January 6, 2007.

Toronto Transit Commission (2011) Service Summary September 4, 2011 to October 8, 2011.

Toronto Transit Commission (2014c) Sheppard Subway All Day Platform Counts.

Toronto Transit Commission (2013) Sheppard Subway Line Construction Key Quantities.

Traffic Data Centre and Safety Bureau (2014a) Finch Ave.

Traffic Data Centre and Safety Bureau (2014b) Sheppard Ave.

Traffic Data Centre and Safety Bureau (2014c) York Mills Rd.

Transit Toronto (2012) The Sheppard Subway. [Online]. 2012. Available from: http://transit.toronto.on.ca/subway/5110.shtml [Accessed: 26 June 2013].

Triathlon Inc. (1999) Toronto and Area Orthophotos.

VandeWeghe, J.R. \& Kennedy, C. (2007) A Spatial Analysis of Residential Greenhouse Gas Emissions in the Toronto Census Metropolitan Area. Journal of Industrial Ecology. [Online] 11 (2), 133-144. Available from: doi:10.1162/jie.2007.1220. 